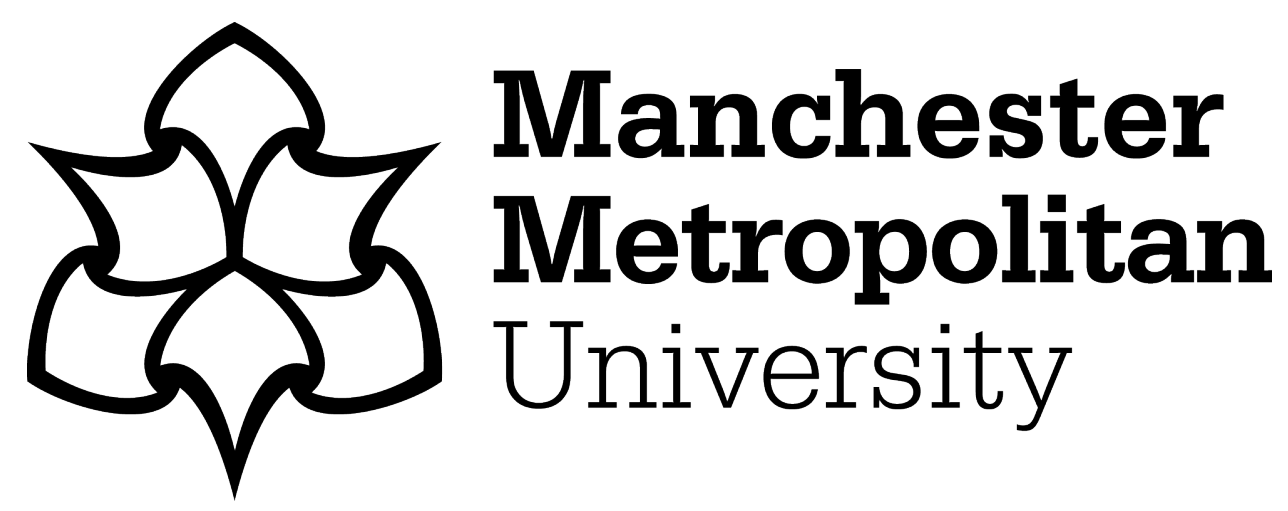

Albarbar, A ORCID logoORCID: https://orcid.org/0000-0003-1484-8224 and Alrweq, Mohmad (2017) Effective Technique for Improving Electrical Performance and Reliability of Fuel Cells. International Journal of Power Electronics and Drive Systems, 8 (4). pp. 1868-1875. ISSN 2088-8694

Downloaded from: https://e-space.mmu.ac.uk/623540/

Version: Published Version

Publisher: Institute of Advanced Engineering and Science (IAES)

DOI: https://doi.org/10.11591/ijpeds.v8i4.pp1868-1875

Usage rights: Creative Commons: Attribution-Noncommercial 4.0

Please cite the published version 


\title{
Effective Technique for Improving Electrical Performance and Reliability of Fuel Cells
}

\author{
M. Alrweq, A. Albarbar \\ Advanced Industrial Diagnostics Research Centre, School of Engineering, Manchester Metropolitan University, \\ Manchester, UK
}

\begin{tabular}{l} 
Article Info \\
\hline Article history: \\
Received Sep 29, 2017 \\
Revised Nov 8, 2017 \\
Accepted Nov 22, 2017 \\
\hline
\end{tabular}

Keyword:

Hydrogen fuel cells Model based systems. Proton exchange membrane Water management

\begin{abstract}
To optimise the electrical performance of proton exchange membrane (PEM) fuel cells, a number of factors have to be precisely monitored and controlled. Water content is one of those factors that has great impact on reliability, durability and performance of PEM fuel cells. The difficulty in controlling water content lies in the inability to determine correct level of water accumulated inside the fuel cell. In this paper, a model-based technique, implemented in COMSOL, is presented for monitoring water content in PEM fuel cells. The model predicts, in real time, water content taking account of other processes occurring in gas channels, across gas diffusion layers (GDL), electrodes, and catalyst layer (CL) and within the membrane to minimize voltage losses and performance degradation. The level of water generated is calculated as function of cell's voltage and current. Model's performance and accuracy are verified using a transparent $500 \mathrm{~mW}$ PEM fuel cell. Results show model predicted current and voltage curves are in good agreement with the experimental measurements. The unique feature of this model is that, no special requirements are needed as only current, and voltage of the PEM fuel cell were measured thus, is expected to pave the path for developing nonintrusive control and monitoring systems for fuel cells.
\end{abstract}

Copyright $@ 2017$ Institute of Advanced Engineering and Science. All rights reserved.

\section{Corresponding Author:}

A. Albarbar,

School of Engineering,

Manchester Metropolitan University,

Manchester, M1 5GD, UK.

Email: a.albarbar@mmu.ac.uk

\section{INTRODUCTION}

Proton exchange membrane (PEM) fuel cells have strong potentials as they offer clean, noise free and relatively inexpensive sources of clear electrical energy. Unfortunately, they suffer some drawbacks including low reliability due to a number of common failure modes such as degradation, poisoning, hydration and dehydration. Hence, optimisation of water content is critical for smooth operation of PEM fuel cells and subject of on-going research works. To minimize voltage losses and enhance performance of PEM fuel cells, water inside them has to be properly managed in line with processes occurring in gas channels, across the GDL (gas diffusion layers), electrolyte, catalyst and membrane. Additionally, membrane needs to be hydrated well in order to enhance its conductivity and to ensure good performance while gas channel and GDL need to be protected from flooding.

In addition to water level in membrane and GDL, relative humidity $(\mathrm{RH})$ and the formation of water droplets in the gas channels are identified as key parameters need to be managed [1]. Water is produced through the electrochemical reaction (see Figure 1 and Equations (1)), with the reactant gas needing to be humidified to assist in membrane humidification in order to enhance ionic conductivity. In-membrane water transport leads to back-diffusion and electro-osmotic drag [2]. Accordingly, the ideal water level is not easy 